Research Article

\title{
Highly Selective Fluorescent Probe for the Detection of Copper (II) and Its Application in Live Cell Imaging
}

\author{
Zhihao Guo, Xiuji Wang, Pei Wei, Yihua Gao (D), and Qin Li \\ Analysis Center, Guangdong Medical University, Dongguan 523808, China \\ Correspondence should be addressed to Yihua Gao; gaoyh@gdmu.edu.cn
}

Received 5 February 2019; Revised 2 April 2019; Accepted 9 April 2019; Published 19 May 2019

Academic Editor: Guido Crisponi

Copyright (C) 2019 Zhihao Guo et al. This is an open access article distributed under the Creative Commons Attribution License, which permits unrestricted use, distribution, and reproduction in any medium, provided the original work is properly cited.

\begin{abstract}
The development of fluorescent methods for the detection of metal ions is of great importance due to their diverse environmental and biological roles. Herein, a rhodamine 6G-based off-on fluorescent probe (L1) with a $t$-butyl pyrrole moiety as the recognition site was designed and synthesized. Photophysical studies show that $\mathbf{L} \mathbf{1}$ exhibits excellent sensitivity and selectivity towards $\mathrm{Cu}^{2+}$ to other metal ions in neutral acetonitrile aqueous media. Mechanism studies suggest that the recognition process may associate with a $\mathrm{Cu}^{2+}$ promoted hydrolysis reaction of $\mathbf{L} \mathbf{1}$. Furthermore, $\mathbf{L} \mathbf{1}$ has been successfully applied in fluorescence imaging of $\mathrm{Cu}^{2+}$ ion in living cells.
\end{abstract}

\section{Introduction}

The exploration of detection methods for environmentally and biologically important metal ions is of great interest to researchers currently $[1,2]$. Among these metal ions, $\mathrm{Cu}^{2+}$ receives great attention because copper is the third most abundant essential metal (after iron and zinc) in the human body and plays an important role in a variety of physiological processes. For example, copper is integrated into various proteins and metalloenzymes that perform basic metabolic functions [3]. Copper deficiency could produce osteoporosis, hyperthyroidism, and coronary heart disease [4]. However, excessive accumulation of copper can cause central nervous system damage and increase the risk of neurodegenerative diseases such as Alzheimer's, Parkinson's, Menken's, and Wilson's diseases [5-8]. Hence, development of sensitive and selective analysis methods for copper ion, especially those that could be utilized in bioimaging, is of great importance in the aspects of understanding the complex physiological functions of copper in the human body.

Traditionally, inductively coupled plasma atomic emission spectrometry (ICP-AES), atomic absorption spectroscopy (AAS), and inductively coupled plasma mass spectrometry (ICP-MS) are used to analyze copper ions [9-11]. However, these methods require sophisticated instruments and complicated and time-consuming processes of sample preparation. Thus, a simple and rapid detection method for quantifying copper ions is necessary. Fluorescence methods, with the advantages of sensitivity, simple operation, and real-time monitoring with fast response time, have been widely used in the detection of metal ions [12-21]. Due to the paramagnetic nature, $\mathrm{Cu}^{2+}$ was usually detected through fluorescence quenching of chemical sensors $[22,23]$, which may result in false-positive results and lesssensitive detection. Among the developed fluorophores, rhodamine derivatives, due to their excellent photophysical properties, such as large absorption coefficients, high fluorescence quantum yields, and long absorption and emission wavelengths, have attracted great attention from researchers [24-29]. In addition, it is well known that the fluorescence emission behaviors of rhodamine derivatives could be adjusted through a spirolactam ring-opening reaction. Spirocycle derivatives of rhodamine are colorless and nonfluorescent due to their nonconjugated structure. However, opening of the spirolactam ring, usually caused by metal ions, will produce intense fluorescence emission and a pink color change. Based on this spirolactam/ring-opened 
amide equilibrium of rhodamine, through introducing proper recognition ligands, researchers have developed many turn-on fluorescent sensors for metal ions [30-40].

Taking into account the criteria mentioned above, we herein incorporated a $t$-butyl pyrrole moiety into the rhodamine fluorophore to form a turn-on fluorescent probe $\mathbf{L} 1$ for the detection of $\mathrm{Cu}^{2+}$. The molecular structure of $\mathbf{L} \mathbf{1}$ was verified by ${ }^{1} \mathrm{H}$ NMR, ${ }^{13} \mathrm{C}$ NMR, and MS spectra. With the addition of $\mathrm{Cu}^{2+}$ to $\mathbf{L 1}$ in a neutral $\mathrm{CH}_{3} \mathrm{CN} / \mathrm{H}_{2} \mathrm{O}$ solution, metal-triggered ring-opening reaction of the spirolactam in L1 took place, resulting in sensitive colorimetric response and fluorescence emission. Mechanism studies suggest that the detection process may associate with a $\mathrm{Cu}^{2+}$ promoted hydrolysis reaction of L1. Furthermore, fluorescence microscopy experiments demonstrated that $\mathbf{L} \mathbf{1}$ could be used to image $\mathrm{Cu}^{2+}$ in living cells.

\section{Materials and Methods}

2.1. General Materials and Apparatus. All chemicals are purchased commercially and used directly without further purification. Deionized water was used throughout, and the $\mathrm{pH}$ was adjusted using diluted sodium hydroxide solution or hydrochloric acid. The $\mathrm{pH}$ value was measured with a Rex pHS-3E pH meter. Silica gel (200-300 mesh) was used for column chromatography. NMR spectra were obtained with a $600 \mathrm{MHz}$ Bruker spectrometer, and tetramethylsilane (TMS) was used as the internal standard. High-resolution mass spectra were measured on an Agilent LCMS 6500 spectrometer. Absorbance spectra were measured on a Shimadzu UV-3101PC spectrometer. Measurements of fluorescence spectra were performed on a Shimadzu RF-5301PC spectrometer. Both excitation and emission slit widths were set at $3 \mathrm{~nm}$. All experiments were operated at about $298 \mathrm{~K}$.

2.2. Procedures of Sensing Experiments. A stock solution of probe L1 $\left(2 \times 10^{-4} \mathrm{M}\right)$ was prepared in $\mathrm{CH}_{3} \mathrm{CN}$. Stock solutions of metal ions $\left(2 \times 10^{-3} \mathrm{M}\right)$ were prepared in deionized water from their chloride salts or nitrate salt $\left(\mathrm{Ag}^{+}\right)$. Working solution of $\mathbf{L} 1\left(10 \mu \mathrm{M}, \mathrm{CH}_{3} \mathrm{CN} / \mathrm{H}_{2} \mathrm{O}, 1: 1, \mathrm{v} / \mathrm{v}\right)$ was freshly prepared prior to spectroscopic experiments by diluting the high-concentration stock solution. In the sensing experiments, each time, a $3 \mathrm{~mL}$ working solution of $\mathbf{L} \mathbf{1}(10 \mu \mathrm{M}$, $\left.\mathrm{CH}_{3} \mathrm{CN} / \mathrm{H}_{2} \mathrm{O}, 1: 1, \mathrm{v} / \mathrm{v}\right)$ was put in a quartz optical cell of $1 \mathrm{~cm}$ optical path length, and appropriate amounts of stock solutions of metal ions were added by a pipette. Spectral data were collected $2 \mathrm{~min}$ after the addition of the ions.

2.3. Synthesis of L1. To a $100 \mathrm{~mL}$ flask with three necks, rhodamine $6 \mathrm{G}$ hydrazine $(2.8 \mathrm{mmol})$, which was synthesized according to reported methods [41], and 5-tert-butylpyrrole2-carbaldehyde $(3.3 \mathrm{mmol})$ were dissolved in $30 \mathrm{~mL}$ methanol. After addition of $0.1 \mathrm{~mL}$ acetic acid, the mixture was stirred and heated to reflux for $16 \mathrm{~h}$. A pale yellow solid obtained was filtered off and washed using cold methanol. The solid was dried in vacuum and further purified by column chromatography $\left(\mathrm{CH}_{2} \mathrm{Cl}_{2} / \mathrm{CH}_{3} \mathrm{OH}=150 / 1\right.$, v/v). Yield: $88.6 \% .{ }^{1} \mathrm{H}$ NMR $\left(600 \mathrm{MHz}, \mathrm{DMSO}-d_{6}\right), \delta(\mathrm{ppm})$ : $10.93(\mathrm{~s}, 1 \mathrm{H}, \mathrm{CNHC}), 8.16(\mathrm{~s}, 1 \mathrm{H}, \mathrm{N}=\mathrm{CH}), 7.84(\mathrm{~d}, J=12 \mathrm{~Hz}$, $1 \mathrm{H}, \operatorname{ArH}), 7.50(\mathrm{~m}, 2 \mathrm{H}, \operatorname{ArH}), 6.94(\mathrm{~d}, \bar{J}=12 \mathrm{~Hz}, 1 \mathrm{H}, \operatorname{ArH})$, $6.30(\mathrm{~s}, 2 \mathrm{H}, \operatorname{ArH}), 6.18(\mathrm{~s}, 2 \mathrm{H}, \operatorname{ArH}), 6.05(\mathrm{~d}, J=6 \mathrm{~Hz}, 1 \mathrm{H}$, $\mathrm{CCHCH}), 5.77(\mathrm{~d}, J=6 \mathrm{~Hz}, 1 \mathrm{H}, \mathrm{CC} \mathrm{HCH}), 5.04(\mathrm{t}, J=6 \mathrm{~Hz}$, $2 \mathrm{H}, \mathrm{CH}_{3} \mathrm{CH}_{2} \mathrm{NH}$ ), 3.12 (q, J=12 Hz, $\left.4 \mathrm{H}, \mathrm{CH}_{3} \mathrm{CH}_{2}\right), 1.85$ (s, $\left.6 \mathrm{H}, \mathrm{ArC}_{3}\right), \underline{1.20}\left(\mathrm{~m}, 15 \mathrm{H}, \mathrm{CH}_{3} \mathrm{CH}_{2}, \mathrm{CCH}_{3}\right) .{ }^{13} \mathrm{C} \mathrm{NMR}$ $\left(150 \mathrm{MHz}, \mathrm{DMSO}-d_{6}\right), \delta$ (ppm): 163.12, 151.96, 150.64, $147.66,146.61,141.63,133.12,128.41,128.31,126.64,126.50$, $123.24,122.60,118.11,112.32,105.03,104.64,95.91,65.00$, 37.44, 31.38, 29.98, 16.96, 14.13. HRMS: $\mathrm{m} / z$ calculated for $\mathrm{M}^{+}, \mathrm{C}_{35} \mathrm{H}_{39} \mathrm{~N}_{5} \mathrm{O}_{2}$, 561.3104. Found: $562.3192(\mathrm{M}+1)$.

2.4. Cell Culture and Fluorescence Imaging. The human breast adenocarcinoma cells MCF7 were cultured in DMEM supplemented with $10 \%$ fetal bovine serum at $37^{\circ} \mathrm{C}$ under an atmosphere containing $5 \% \mathrm{CO}_{2}$. Before the experiments, the MCF7 cells were washed with PBS and then incubated with $10 \mu \mathrm{M} \mathrm{L1}$ at $37^{\circ} \mathrm{C}$ for $30 \mathrm{~min}$. After removal of excess probe and washed with PBS, the MCF7 cells were incubated with $20 \mu \mathrm{M} \mathrm{CuCl}{ }_{2}$ for another $30 \mathrm{~min}$. The MCF7 cells were rinsed with $\mathrm{PBS}$ again and live-cell imaging was conducted using an EVOS FL Auto microscope.

\section{Results and Discussion}

Compound L1 was easily synthesized from rhodamine 6G through a two-step reaction (Scheme 1). After purification by column chromatography $\left(\mathrm{CH}_{2} \mathrm{Cl}_{2} / \mathrm{CH}_{3} \mathrm{OH}=150 / 1\right.$, v/v), L1 was obtained in an $88.6 \%$ yield. The molecular structure was verified by ${ }^{1} \mathrm{H}$ NMR, ${ }^{13} \mathrm{C}$ NMR, and MS spectra (Figures S1-S3). The $m / z$ value of the molecular ion peak in the HRMS spectra was in good accordance with the accurate molecular weight with small derivation. Similar with other spirocycle derivatives of rhodamine, the solution of $\mathbf{L} \mathbf{1}$ in neutral $\mathrm{CH}_{3} \mathrm{CN} / \mathrm{H}_{2} \mathrm{O}$ media was colorless and weakly fluorescent, indicating that it existed mainly in the form of spirolactam. In addition, a characteristic spirocycle carbon chemical shift at $65.0 \mathrm{ppm}$ in the ${ }^{13} \mathrm{C}$ NMR spectra was observed, which further supported this estimation [42].

The absorption spectrum of $\mathbf{L 1}(10 \mu \mathrm{M})$ in neutral $\mathrm{CH}_{3} \mathrm{CN} / \mathrm{H}_{2} \mathrm{O}(1: 1, \mathrm{v} / \mathrm{v})$ solution is shown in Figure 1. No absorption peaks in the visible wavelength range was exhibited, suggesting that $\mathbf{L} \mathbf{1}$ existed with the structure of spirolactam. Once the solution of $\mathrm{Cu}^{2+}$ was added, a new peak was detected at $525 \mathrm{~nm}$. With the increase of $\mathrm{Cu}^{2+}$ concentration, the intensity of the peak was gradually enhanced, which could be interpreted as the transform from a spirolactam structure to a ring-opened form of L1. Correspondingly, the color of the solution changed from colorless to purple, which help to achieve the naked-eye recognition of $\mathrm{Cu}^{2+}$ ion. As shown in Figure 1, with the increasing concentration of $\mathrm{Cu}^{2+}$, the absorption value of $\mathbf{L 1}(10 \mu \mathrm{M})$ was found to increase linearly in the range of $2 \mu \mathrm{M}-14 \mu \mathrm{M}$ at $525 \mathrm{~nm}$. The selective sensory studies of $\mathbf{L 1}(10 \mu \mathrm{M})$ in neutral $\mathrm{CH}_{3} \mathrm{CN} / \mathrm{H}_{2} \mathrm{O}$ solution were then extended to other metal ions $\left(\mathrm{Cr}^{3+}, \mathrm{Al}^{3+}, \mathrm{Fe}^{3+}, \mathrm{Ca}^{2+}, \mathrm{Ba}^{2+}, \mathrm{Co}^{2+}, \mathrm{Fe}^{2+}, \mathrm{Hg}^{2+}\right.$, $\mathrm{Mg}^{2+}, \mathrm{Mn}^{2+}, \mathrm{Ni}^{2+}, \mathrm{Pd}^{2+}, \mathrm{Zn}^{2+}, \mathrm{Ag}^{+}, \mathrm{Li}^{+}, \mathrm{K}^{+}, \mathrm{Na}^{+}$, and $\left.\mathrm{Sn}^{4+}\right)$. When 1 equiv metal ions were added into the relevant 


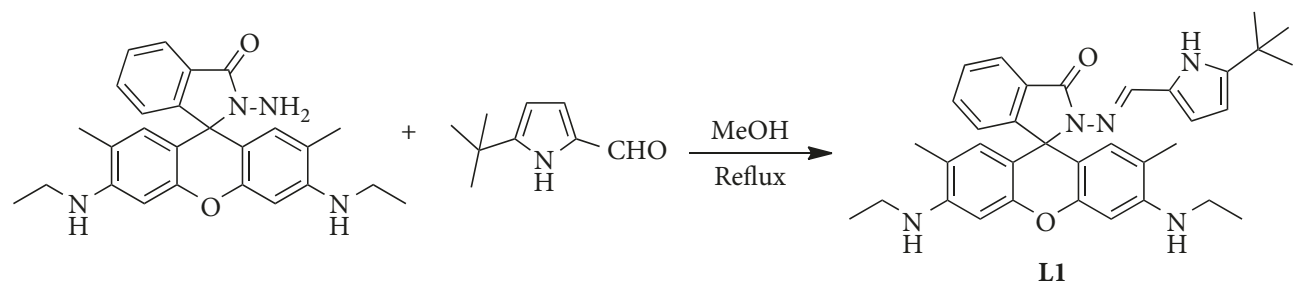

Scheme 1: Synthesis of probe $\mathbf{L} 1$.

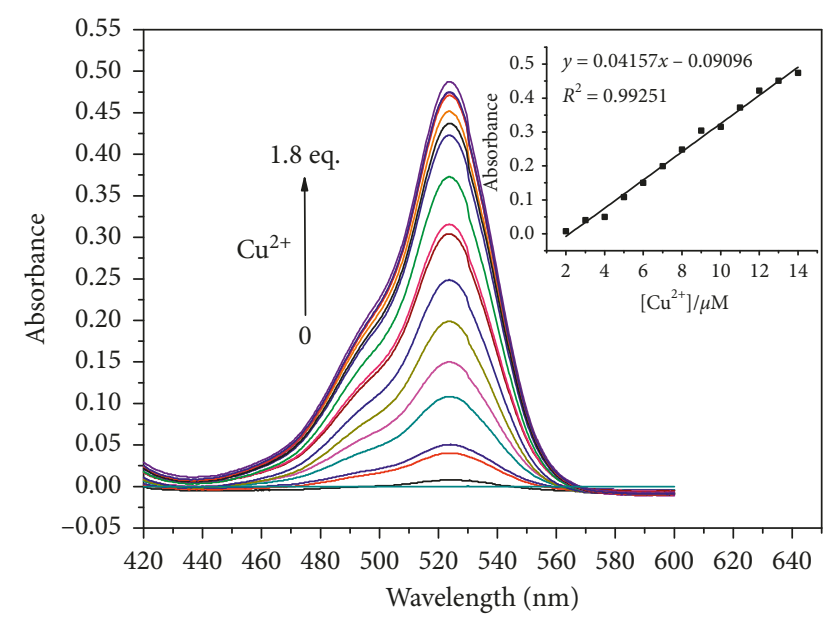

FIGURE 1: Absorbance spectra of $\mathbf{L 1}(10 \mu \mathrm{M})$ containing different concentrations of $\mathrm{Cu}^{2+}(0-18 \mu \mathrm{M})$ in $\mathrm{CH}_{3} \mathrm{CN} / \mathrm{H}_{2} \mathrm{O}$ solution $(1: 1, \mathrm{v} /$ v). Inset: the absorbance at $525 \mathrm{~nm}$ as a function of $\mathrm{Cu}^{2+}$ concentration $(2-14 \mu \mathrm{M})$.

solution, only $\mathrm{Cu}^{2+}$ could induce a purple color and an obvious increase of absorbance at $525 \mathrm{~nm}$ (Figure 2). $\mathrm{Al}^{3+}$ exhibited weak absorption response, and the other metal ions showed almost no absorbance increase in the same condition. The results indicated that $\mathbf{L} \mathbf{1}$ showed high selectivity towards $\mathrm{Cu}^{2+}$ in the detection of metal ions.

The fluorescence sensing behavior of $\mathbf{L 1}$ for $\mathrm{Cu}^{2+}$ in neutral $\mathrm{CH}_{3} \mathrm{CN} / \mathrm{H}_{2} \mathrm{O}$ solution $(10 \mu \mathrm{M}, 1: 1$, v/v) was also investigated. When no $\mathrm{Cu}^{2+}$ was added, the free $\mathbf{L} \mathbf{1}$ solution had little fluorescence at the excitation wavelength of $500 \mathrm{~nm}$ due to the spirocyclic form of its molecular structure. However, similar to the results of the absorption experiments, once the solution of $\mathrm{Cu}^{2+}$ was added, an obvious increase of the fluorescence intensity at $545 \mathrm{~nm}$ (Figure 3) could be detected, which could be ascribed to the generation of ring-opened conjugate structure in the rhodamine moiety. The fluorescence intensity at $545 \mathrm{~nm}$ of $\mathbf{L 1}(10 \mu \mathrm{M})$ was linear with the concentration of $\mathrm{Cu}^{2+}$ in the range of $2 \mu \mathrm{M}-26 \mu \mathrm{M}$, and the detection limit of $\mathrm{Cu}^{2+}$ was calculated as $0.38 \mu \mathrm{M}(\mathrm{S} / \mathrm{N}=3)$. The fluorescence quantum yield was calculated to be 0.19 in the presence of $\mathrm{Cu}^{2+}$ ion $(26 \mu \mathrm{M})$ by using rhodamine 6G as the standard $\left(\Phi_{\mathrm{f}}=0.94\right.$ in ethanol) [43]. The selectivity of $\mathbf{L} \mathbf{1}$ towards $\mathrm{Cu}^{2+}$ over other cations was satisfactory. On excitation at $500 \mathrm{~nm}$, no obvious spectral change of $\mathbf{L} \mathbf{1}\left(10 \mu \mathrm{M}, \mathrm{CH}_{3} \mathrm{CN} / \mathrm{H}_{2} \mathrm{O}, 1: 1, \mathrm{v} / \mathrm{v}\right)$ was observed with the addition of $\mathrm{Cr}^{3+}, \mathrm{Al}^{3+}, \mathrm{Fe}^{3+}, \mathrm{Ca}^{2+}, \mathrm{Ba}^{2+}$, $\mathrm{Co}^{2+}, \mathrm{Fe}^{2+}, \mathrm{Hg}^{2+}, \mathrm{Mg}^{2+}, \mathrm{Mn}^{2+}, \mathrm{Ni}^{2+}, \mathrm{Pd}^{2+}, \mathrm{Zn}^{2+}, \mathrm{Ag}^{+}, \mathrm{Li}^{+}, \mathrm{K}^{+}$,

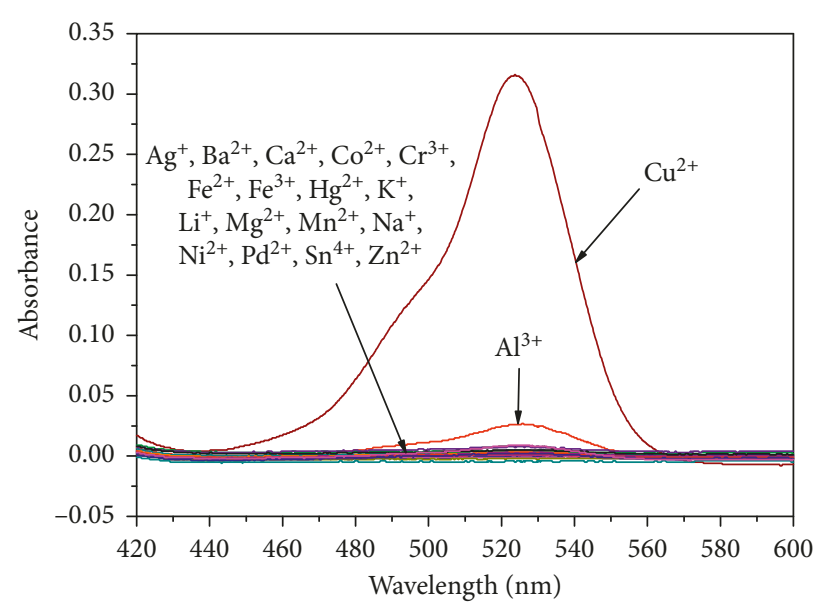

FIgURE 2: Absorbance spectra of $\mathbf{L 1}(10 \mu \mathrm{M})$ with addition of $10 \mu \mathrm{M}$ various metal ions in $\mathrm{CH}_{3} \mathrm{CN} / \mathrm{H}_{2} \mathrm{O}$ solution $(1: 1, \mathrm{v} / \mathrm{v})$.

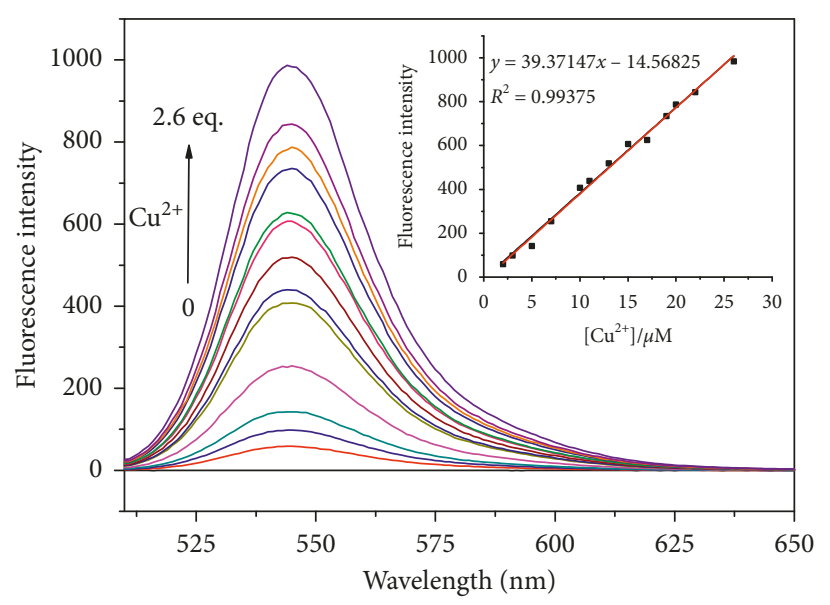

FIgURE 3: Fluorescence spectra of $\mathbf{L} \mathbf{1}(10 \mu \mathrm{M})$ containing different concentrations of $\mathrm{Cu}^{2+}(0-26 \mu \mathrm{M})$ in $\mathrm{CH}_{3} \mathrm{CN} / \mathrm{H}_{2} \mathrm{O}$ solution $(1: 1, \mathrm{v} /$ v). Excitation was performed at $500 \mathrm{~nm}$. Inset: fluorescence intensity at $545 \mathrm{~nm}$ as a function of $\mathrm{Cu}^{2+}$ concentration $(2-26 \mu \mathrm{M})$.

$\mathrm{Na}^{+}$, and $\mathrm{Sn}^{4+}(10 \mu \mathrm{M})$. In contrast, more than 500 -fold fluorescence intensity increase was detected when the same amount of $\mathrm{Cu}^{2+}$ ion was added (Figure 4). In order to further evaluate the selectivity of $\mathbf{L} \mathbf{1}$ towards $\mathrm{Cu}^{2+}$ among other metal ions, the interference experiments were investigated. As shown in Figure 5, no obvious changes were observed in the $\mathrm{Cu}^{2+}$-induced fluorescence emission of $\mathbf{L} \mathbf{1}$ when comparing the spectra data obtained in the presence and absence of other metal ions. These results indicated that $\mathbf{L} \mathbf{1}$ could be 


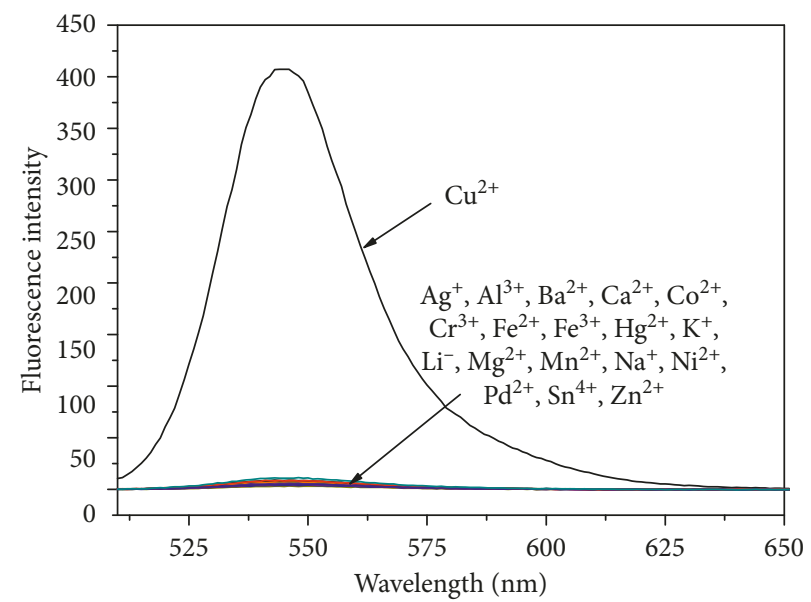

FIgURE 4: Fluorescence spectra of $\mathbf{L} \mathbf{1}(10 \mu \mathrm{M})$ with addition of $10 \mu \mathrm{M}$ various metal ions in $\mathrm{CH}_{3} \mathrm{CN} / \mathrm{H}_{2} \mathrm{O}$ solution $(1: 1$, v/v). Excitation was performed at $500 \mathrm{~nm}$.

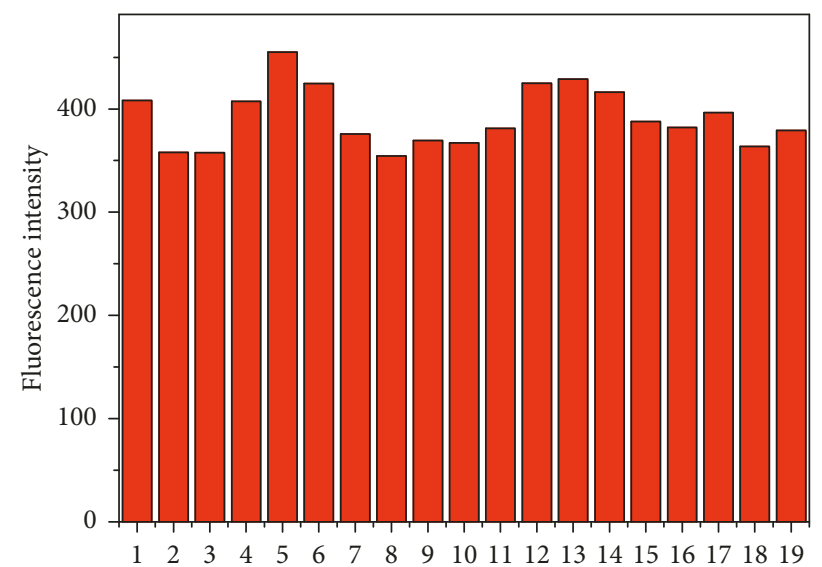

FIGURE 5: Fluorescence intensity at $545 \mathrm{~nm}$ of $\mathbf{L} \mathbf{1}(10 \mu \mathrm{M})$ with addition of $10 \mu \mathrm{M} \mathrm{Cu}^{2+}$ in the absence (blank) and presence of various metal ions $(50 \mu \mathrm{M})$ in $\mathrm{CH}_{3} \mathrm{CN} / \mathrm{H}_{2} \mathrm{O}$ solution $(1: 1, \mathrm{v} / \mathrm{v})$. (1) blank, (2) $\mathrm{Ag}^{+}$, (3) $\mathrm{Al}^{3+}$, (4) $\mathrm{Ba}^{2+}$, (5) $\mathrm{Ca}^{2+}$, (6) $\mathrm{Co}^{2+}$, (7) $\mathrm{Cr}^{3+}$, (8) $\mathrm{Fe}^{2+}$, (9) $\mathrm{Fe}^{3+}$, (10) $\mathrm{Hg}^{2+}$, (11) $\mathrm{K}^{+}$, (12) $\mathrm{Li}^{+}$, (13) $\mathrm{Mg}^{2+}$, (14) $\mathrm{Mn}^{2+}$, (15) $\mathrm{Na}^{+}$, (16) $\mathrm{Ni}^{2+}$, (17) $\mathrm{Pd}^{2+}$, (18) $\mathrm{Sn}^{4+}$, and (19) $\mathrm{Zn}^{2+}$. Excitation was performed at $500 \mathrm{~nm}$.

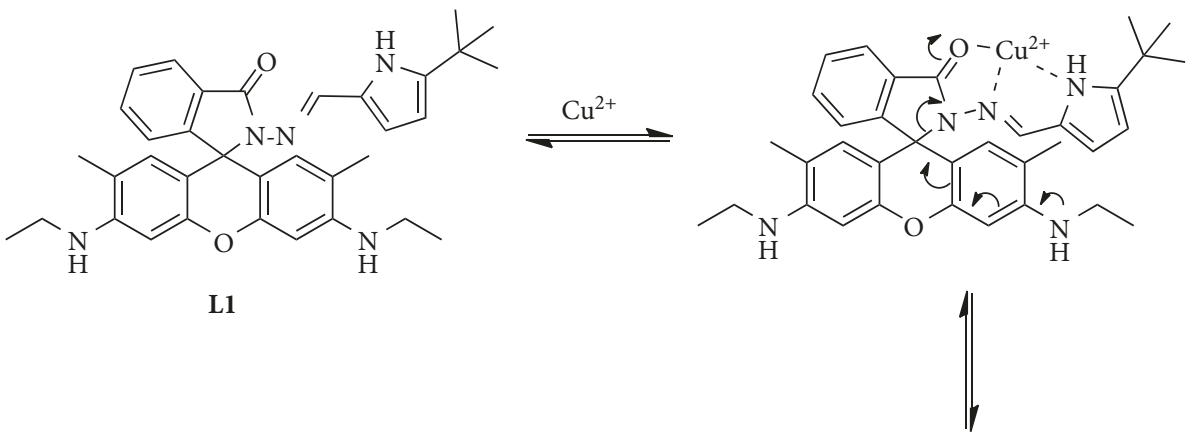<smiles>CCNc1cc2oc3cc(=[NH+]CC)c(C)cc-3c(-c3ccccc3C(=O)[O-])c2cc1C</smiles>

SCheme 2: The proposed reaction mechanism of $\mathbf{L} \mathbf{1}$ with $\mathrm{Cu}^{2+}$. 


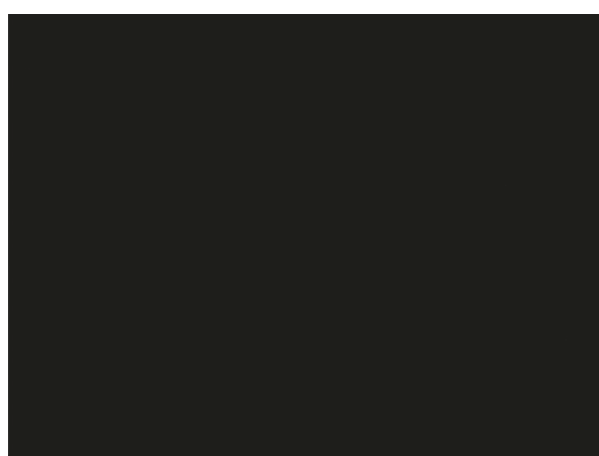

(a)

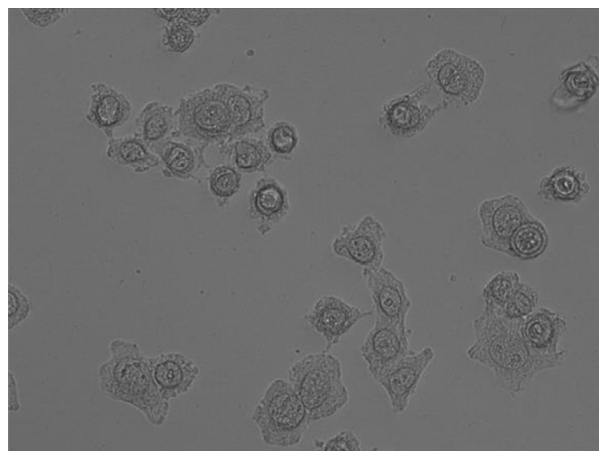

(c)

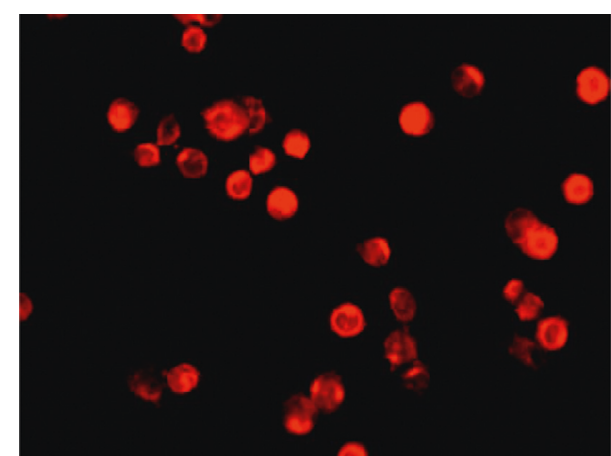

(b)

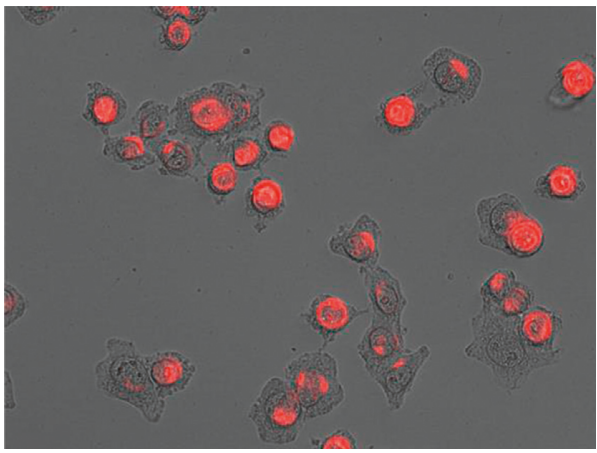

(d)

Figure 6: (a) Fluorescence image of MCF7 cells incubated with L1 $(10 \mu \mathrm{M})$ for $30 \mathrm{~min}$ at $37^{\circ} \mathrm{C}$. (b) Fluorescence image of MCF7 cells incubated with $\mathbf{L} 1(10 \mu \mathrm{M})$ for $30 \mathrm{~min}$ and then incubated with $\mathrm{Cu}^{2+}(20 \mu \mathrm{M})$ for another $30 \mathrm{~min}$ at $37^{\circ} \mathrm{C}$. (c) Brightfield image of cells shown in (b). (d) The overlay image of b and c.

used as a selective $\mathrm{Cu}^{2}$ fluorescent sensor without interference from other metal ions.

The influence of solution $\mathrm{pH}$ on the fluorescence response towards $\mathrm{Cu}^{2+}$ of $\mathbf{L} \mathbf{1}$ was studied. As shown in Figure S4, no obvious fluorescence could be found for free L1 between $\mathrm{pH} 4.0$ and 8.0, indicating that the spirolactam structure still dominated in this $\mathrm{pH}$ range. However, with the addition of $\mathrm{Cu}^{2+}$, fluorescence change of $\mathbf{L} \mathbf{1}$ was observed with different fluorescence enhancement efficiency under different $\mathrm{pH}$ values (Figure S5). A marked fluorescence response towards $\mathrm{Cu}^{2+}$ was achieved in a $\mathrm{pH}$ range from 7 to 8. These results indicated that $\mathbf{L} \mathbf{1}$ could be used as a fluorescent probe for the detection of $\mathrm{Cu}^{2+}$ in physiological $\mathrm{pH}$ conditions.

The effects of reaction media for the detection of $\mathrm{Cu}^{2+}$ by L1 were also studied. As shown in Figure S6, in the presence of 1 equiv. $\mathrm{Cu}^{2+}$, the fluorescence signal value of $\mathbf{L} \mathbf{1}$ reached the maximum when acetonitrile content was at 50\%-60\%. As a result, $50 \%$ aqueous acetonitrile was employed in all optical experiments. The response time of the detection system on fluorescence emission was studied to evaluate the sensitivity of $\mathbf{L} \mathbf{1}$ towards $\mathrm{Cu}^{2+}$. After addition of 1 equiv. $\mathrm{Cu}^{2+}$, the fluorescence intensity of $\mathbf{L} \mathbf{1}$ increased rapidly and reached maximum after two minutes and did not increase with the prolongation of reaction time (Figure S7). These results indicated that $\mathbf{L} \mathbf{1}$ was sensitive for the detection of $\mathrm{Cu}^{2+}$ in the aqueous acetonitrile solution, and $2 \mathrm{~min}$ was selected as the detection time in this research.
In order to illustrate the interaction mechanism between $\mathrm{Cu}^{2+}$ and $\mathbf{L} \mathbf{1}$, excess (10 equiv) $\mathrm{Na}_{2}$ EDTA was added to the solution of $\mathbf{L 1}$ in neutral $\mathrm{CH}_{3} \mathrm{CN} / \mathrm{H}_{2} \mathrm{O}$ solution $(10 \mu \mathrm{M}, 1: 1$, $\mathrm{v} / \mathrm{v})$ containing $\mathrm{Cu}^{2+}$ ion $(10 \mu \mathrm{M})$. No obvious decrease in the fluorescent intensity or color change was observed after the addition, indicating that the detection of $\mathrm{Cu}^{2+}$ ion by $\mathbf{L} \mathbf{1}$ was an irreversible process (Figure S8). HRMS experiments were carried out to analyze the reaction products of $\mathrm{Cu}^{2+}$ and L1. The peak at $m / z=415.2025$ was ascribed to rhodamine $6 \mathrm{G}\left(\mathrm{M}+1 ; \mathrm{m} / z\right.$ calculated for $\mathrm{M}^{+}, \mathrm{C}_{26} \mathrm{H}_{26} \mathrm{~N}_{2} \mathrm{O}_{3}$, 414.1943), indicating rhodamine $6 \mathrm{G}$ as a final product (Figure S9). Moreover, the addition of $\mathrm{Cu}^{2+}$ into the solution of $\mathbf{L 1}$ in pure $\mathrm{CH}_{3} \mathrm{CN}$ resulted in no fluorescent emission or color change. Based on these experimental results, a mechanism involving $\mathrm{Cu}^{2+}$-promoted redox hydrolysis of L1 was proposed (Scheme 2), which was similar to that of the sensing towards $\mathrm{Cu}^{2+}$ by rhodamine B hydrazide [44].

For further studying the practical application of $\mathbf{L} \mathbf{1}$ in the detection of $\mathrm{Cu}^{2+}$, fluorescence imaging experiments were carried out in MCF7 cells. The MCF7 cells were incubated with $\mathbf{L} \mathbf{1}$ for 30 min and washed with PBS. As shown in Figure 6(a), no intracellular fluorescence was observed in the image. However, after subsequent treatment with $\mathrm{CuCl}_{2}$ at the same conditions for another $30 \mathrm{~min}$, strong fluorescence in the MCF7 cells was observed (Figure 6(b)). These results suggest that $\mathbf{L} \mathbf{1}$ could pass through the cell membrane and be used for the detection of $\mathrm{Cu}^{2+}$ in living cells. The cytotoxicity tests were studied by MTT assay with the concentrations of L1 
from 0 to $30 \mu \mathrm{M}$ (Figure S10). Experimental results showed that more than $95 \%$ of the MCF7 cells were viable after incubation with $\mathbf{L 1}$ for $24 \mathrm{~h}$ at $37^{\circ} \mathrm{C}$, indicating that $\mathbf{L 1}$ has low cytotoxicity to cells in this dosage range.

\section{Conclusion}

In summary, a new colorimetric and fluorescent probe L1 for $\mathrm{Cu}^{2+}$ was developed through the combination of rhodamine $6 \mathrm{G}$ and a pyrrole moiety. As a turn-on fluorescent probe, $\mathbf{L} 1$ exhibited excellent sensitivity and selectivity for $\mathrm{Cu}^{2+}$ detection in acetonitrile aqueous media with a low detection limit. Moreover, fluorescence bioimaging experiments confirmed that $\mathbf{L} \mathbf{1}$ could be used to detect intracellular $\mathrm{Cu}^{2+}$ in living cells.

\section{Data Availability}

The data used to support the findings of this study are available from the corresponding author upon request.

\section{Conflicts of Interest}

The authors report no conflicts of interest.

\section{Authors' Contributions}

Zhihao Guo and Xiuji Wang contributed equally to this work.

\section{Acknowledgments}

This work was supported by the National Natural Science Foundation of China (21502024 and 81503104) and the Doctoral Scientific Research Foundation of Guangdong Province (2014A030310471 and 2018A030310112).

\section{Supplementary Materials}

Figure S1: ${ }^{1} \mathrm{H}$ NMR of compound $\mathbf{L} 1\left(600 \mathrm{MHz}, \mathrm{DMSO}-d_{6}\right)$. Figure S2: ${ }^{13} \mathrm{C}$ NMR of compound L1 $\left(150 \mathrm{MHz}\right.$, DMSO- $\left.d_{6}\right)$. Figure S3: high-resolution mass spectra of L1. Figure S4: effect of $\mathrm{pH}$ on fluorescence intensity at $545 \mathrm{~nm}$ of L1 $(10 \mu \mathrm{M})$ in $\mathrm{CH}_{3} \mathrm{CN} / \mathrm{H}_{2} \mathrm{O}$ solution $(1: 1, \mathrm{v} / \mathrm{v})$. Excitation was performed at $500 \mathrm{~nm}$. Figure S5: effect of $\mathrm{pH}$ on fluorescence intensity at $545 \mathrm{~nm}$ of $\mathbf{L 1}(10 \mu \mathrm{M})$ in the presence of $10 \mu \mathrm{M}$ $\mathrm{Cu}^{2+}$ in $\mathrm{CH}_{3} \mathrm{CN} / \mathrm{H}_{2} \mathrm{O}$ solution $(1: 1, \mathrm{v} / \mathrm{v})$. Excitation was performed at $500 \mathrm{~nm}$. Figure S6: effect of acetonitrile content on fluorescence intensity of $\mathbf{L} \mathbf{1}(10 \mu \mathrm{M})$ in the presence of $10 \mu \mathrm{M} \mathrm{Cu}{ }^{2+}$ in $\mathrm{CH}_{3} \mathrm{CN} / \mathrm{H}_{2} \mathrm{O}$ solution. Excitation was performed at $500 \mathrm{~nm}$. Figure S7: time course of the response of L1 $(10 \mu \mathrm{M})$ to 1 equiv. of $\mathrm{Cu}^{2+}$ in $\mathrm{CH}_{3} \mathrm{CN} / \mathrm{H}_{2} \mathrm{O}$ solution. Figure S8: fluorescence spectra of $\mathbf{L} \mathbf{1}(10 \mu \mathrm{M})$ with addition of $10 \mu \mathrm{M} \mathrm{Cu}^{2+}$ in the absence and presence of 10 equiv. $\mathrm{Na}_{2}$ EDTA in $\mathrm{CH}_{3} \mathrm{CN} / \mathrm{H}_{2} \mathrm{O}$ solution $(1: 1, \mathrm{v} / \mathrm{v})$. Figure S9: mass spectrum for the reaction products of $\mathrm{Cu}^{2+}$ and $\mathbf{L} \mathbf{1}$ in $\mathrm{CH}_{3} \mathrm{CN} / \mathrm{H}_{2} \mathrm{O}$ solution $(1: 1, \mathrm{v} / \mathrm{v})$. Figure $\mathrm{S} 10$ : the viability of MCF7 cells incubated with $\mathbf{L} 1$ of different concentrations. (Supplementary Materials)

\section{References}

[1] B. Champagne, A. Plaquet, J.-L. Pozzo, V. Rodriguez, and F. Castet, "Nonlinear optical molecular switches as selective cation sensors," Journal of the American Chemical Society, vol. 134, no. 19, pp. 8101-8103, 2012.

[2] J. F. Zhang, Y. Zhou, J. Yoon, and J. S. Kim, "Recent progress in fluorescent and colorimetric chemosensors for detection of precious metal ions (silver, gold and platinum ions)," Chemical Society Reviews, vol. 40, no. 7, pp. 3416-3429, 2011.

[3] E. L. Que, D. W. Domaille, and C. J. Chang, "Metals in neurobiology: probing their chemistry and biology with molecular imaging," Chemical Reviews, vol. 108, no. 5, pp. 1517-1549, 2008.

[4] M. Klatka, A. Błażewicz, M. Partyka, W. Kołłątaj, E. Zienkiewicz, and R. Kocjan, "Concentration of selected metals in whole blood, plasma, and urine in short stature and healthy children," Biological Trace Element Research, vol. 166, no. 2, pp. 142-148, 2015.

[5] M. Suneetha, P. Suman, S. M. Robinson, D. Shinya, W. A. Banks, and E. Nuran, "Copper complexing decreases the ability of amyloid beta peptide to cross the BBB and enter brain parenchyma," Peptides, vol. 28, no. 7, pp. 1424-1432, 2007.

[6] E. Gaggelli, H. Kozlowski, D. Valensin, and G. Valensin, "Copper homeostasis and neurodegenerative disorders (Alzheimer's, prion, and Parkinson's diseases and amyotrophic lateral sclerosis)," Chemical Reviews, vol. 106, no. 6, pp. 1995-2044, 2006.

[7] C. Deraeve, C. Boldron, A. Maraval et al., "Preparation and study of new poly-8-hydroxyquinoline chelators for an antiAlzheimer strategy," Chemistry - A European Journal, vol. 14, no. 2, pp. 682-696, 2008.

[8] I. A. Koval, P. Gamez, C. Belle, K. Selmeczi, and J. Reedijk, "Synthetic models of the active site of catechol oxidase: mechanistic studies," Chemical Society Reviews, vol. 35, no. 9, pp. 814-840, 2006.

[9] M. Faraji, Y. Yamini, and S. Shariati, "Application of cotton as a solid phase extraction sorbent for on-line preconcentration of copper in water samples prior to inductively coupled plasma optical emission spectrometry determination," Journal of Hazardous Materials, vol. 166, no. 2-3, pp. 1383-1388, 2009.

[10] N. Pourreza and R. Hoveizavi, "Simultaneous preconcentration of $\mathrm{Cu}, \mathrm{Fe}$ and $\mathrm{Pb}$ as methylthymol blue complexes on naphthalene adsorbent and flame atomic absorption determination," Analytica Chimica Acta, vol. 549, no. 1-2, pp. 124-128, 2005.

[11] N. Pourmand, M. M. Sanagi, A. A. Naim, W. A. Wan Ibrahim, and U. Baig, "Dispersive micro-solid phase extraction method using newly prepared poly(methyl methacrylate) grafted agarose combined with ICP-MS for the simultaneous determination of $\mathrm{Cd}, \mathrm{Ni}, \mathrm{Cu}$ and $\mathrm{Zn}$ in vegetable and natural water samples," Analytical Methods, vol. 7, no. 7, pp. 32153223, 2015.

[12] A. B. More, S. Mula, S. Thakare et al., "An acac-BODIPY dye as a reversible "ON-OFF-ON" fluorescent sensor for $\mathrm{Cu}^{2+}$ and $\mathrm{S}^{2-}$ ions based on displacement approach," Journal of $\mathrm{Lu}$ minescence, vol. 190, pp. 476-484, 2017.

[13] J. Park and Y. Kim, "A colorimetric probe for the selective naked-eye detection of $\mathrm{Pb}(\mathrm{II})$ ions in aqueous media," $\mathrm{An}$ alyst, vol. 137, no. 14, pp. 3246-3248, 2012.

[14] Y. Wei, D. Cheng, T. Ren, Y. Li, Z. Zeng, and L. Yuan, "Design of NIR chromenylium-cyanine fluorophore library for 
"switch-on" and ratiometric detection of bio-active species in vivo," Analytical Chemistry, vol. 88, no. 3, pp. 1842-1849, 2016.

[15] I. Roy, J.-Y. Shin, D. Shetty, J. K. Khedkar, J. H. Park, and K. Kim, "E-Bodipy fluorescent chemosensor for $\mathrm{Zn} 2^{+}$ion," Journal of Photochemistry and Photobiology A: Chemistry, vol. 331, pp. 233-239, 2016.

[16] H. Lu, L. Xiong, H. Liu et al., "A highly selective and sensitive fluorescent turn-on sensor for $\mathrm{Hg}^{2+}$ and its application in live cell imaging," Organic \& Biomolecular Chemistry, vol. 7, no. 12, pp. 2554-2558, 2009.

[17] C. Baslak and A. N. Kursunlu, "Naked-eye fluorescent sensor for copper (II) ion based on naphthalene conjugate BODIPY dye," Photochemical \& Photobiological Sciences, vol. 17, no. 8, pp. 1091-1097, 2018.

[18] W. Gao, H. Li, and S. Pu, "A highly selective fluorescent probe for $\mathrm{Cu}^{2+}$ based on a diarylethene with a benzo[1,2,5] oxadiazol-4-ylamine schiff base unit," Journal of Photochemistry and Photobiology A: Chemistry, vol. 364, pp. 208218, 2018.

[19] S. Guo, G. Liu, C. Fan, and S. Pu, "A new diarylethene-derived probe for colorimetric sensing of $\mathrm{Cu}$ (II) and fluorometric sensing of $\mathrm{Cu}(\mathrm{II})$ and $\mathrm{Zn}(\mathrm{II})$ : photochromism and high selectivity," Sensors and Actuators B: Chemical, vol. 266, pp. 603-613, 2018.

[20] Z. Shi, Y. Tu, R. Wang, G. Liu, and S. Pu, "Highly sensitive and selective turn-on fluorescent sensor for dual recognition of $\mathrm{Cu}^{2+}$ and $\mathrm{CN}^{-}$based on a methylquinoline derivative," Dyes and Pigments, vol. 149, pp. 764-773, 2018.

[21] H. Kang, C. Fan, H. Xu, G. Liu, and S. Pu, "A highly selective fluorescence switch for $\mathrm{Cu}^{2+}$ and $\mathrm{Fe}^{3+}$ based on a new diarylethene with a triazole-linked rhodamine 6G unit," Tetrahedron, vol. 74, no. 33, pp. 4390-4399, 2018.

[22] K. A. Mccall and C. A. Fierke, "Colorimetric and fluorimetric assays to quantitate micromolar concentrations of transition metals," Analytical Biochemistry, vol. 284, no. 2, pp. 307-315, 2000.

[23] P. Chavez-Crooker, N. Garrido, and G. A. Ahearn, "Copper transport by lobster hepatopancreatic epithelial cells separated by centrifugal elutriation: measurements with the fluorescent dye Phen Green," Journal of Experimental Biology, vol. 204, no. 8, pp. 1433-1444, 2001.

[24] F. Amat-Guerri, A. Costela, J. M. Figuera, F. Florido, and R. Sastre, "Laser action from rhodamine 6G-doped poly (2hydroxyethyl methacrylate) matrices with different crosslinking degrees," Chemical Physics Letters, vol. 209, no. 4, pp. 352-356, 1993.

[25] X. Li, X. Gao, W. Shi, and H. Ma, "Design strategies for watersoluble small molecular chromogenic and fluorogenic probes," Chemical Reviews, vol. 114, no. 1, pp. 590-659, 2014.

[26] X. Chen, T. Pradhan, F. Wang, J. S. Kim, and J. Yoon, "Fluorescent chemosensors based on spiroring-opening of xanthenes and related derivatives," Chemical Reviews, vol. 112, no. 3, pp. 1910-1956, 2012.

[27] L. Yuan, W. Lin, K. Zheng, and S. Zhu, "FRET-based smallmolecule fluorescent probes: rational design and bioimaging applications," Accounts of Chemical Research, vol. 46, no. 7, pp. 1462-1473, 2013.

[28] Y. Yang, Q. Zhao, W. Feng, and F. Li, "Luminescent chemodosimeters for bioimaging," Chemical Reviews, vol. 113, no. 1, pp. 192-270, 2013.

[29] D.-G. Cho and J. L. Sessler, "Modern reaction-based indicator systems," Chemical Society Reviews, vol. 38, no. 6, pp. 16471662, 2009.
[30] A. K. Bhanja, S. Mishra, K. Das Saha, and C. Sinha, "A fluorescence "turn-on" chemodosimeter for the specific detection of $\mathrm{Pd}^{2+}$ by a rhodamine appended schiff base and its application in live cell imaging," Dalton Transactions, vol. 46, no. 28, pp. 9245-9252, 2017.

[31] X. Bao, X. Cao, X. Nie et al., "A new selective fluorescent chemical sensor for $\mathrm{Fe}^{3+}$ based on rhodamine $\mathrm{B}$ and $\mathrm{a}$ 1,4,7,10-tetraoxa-13-azacyclopentadecane conjugate and its imaging in living cells," Sensors and Actuators B: Chemical, vol. 208, pp. 54-66, 2015.

[32] J. Liu and Y. Qian, "A novel naphthalimide-rhodamine dye: intramolecular fluorescence resonance energy transfer and ratiometric chemodosimeter for $\mathrm{Hg}^{2+}$ and $\mathrm{Fe}^{3+}$," Dyes and Pigments, vol. 136, pp. 782-790, 2017.

[33] S. Guang, G. Wei, Z. Yan et al., "A novel turn-on fluorescent probe for multi-channel detection of $\mathrm{Zn}^{2+}$ and $\mathrm{Bi}^{3+}$ with different action mechanisms," Analyst, vol. 143, no. 2, pp. 449-457, 2017.

[34] Y. Zheng, M. She, S. Ma et al., "Rhodamine based guanidinobenzimidazole functionalized fluorescent probe for tetravalent tin and its application in living cells imaging," Sensors and Actuators B: Chemical, vol. 242, pp. 872-879, 2016.

[35] M. V. Tutov, A. A. Sergeev, P. A. Zadorozhny, S. Y. Bratskaya, and A. Y. Mironenko, "Dendrimeric rhodamine based fluorescent probe for selective detection of Au," Sensors and Actuators B: Chemical, vol. 273, pp. 916-920, 2018.

[36] Z. Xu, L. Zhang, R. Guo et al., "A highly sensitive and selective colorimetric and off-on fluorescent chemosensor for $\mathrm{Cu}^{2+}$ based on rhodamine B derivative," Sensors and Actuators B: Chemical, vol. 156, no. 2, pp. 546-552, 2011.

[37] H. Xu, H. Ding, C. Fan, G. Liu, and S. Pu, "A multi-responsive diarylethene-rhodamine $6 \mathrm{G}$ derivative for sequential detection of $\mathrm{Cr}^{3+}$ and $\mathrm{CO}_{3}{ }^{2-}$," Tetrahedron, vol. 74, no. 27, pp. 3489-3497, 2018.

[38] Y. Jiao, L. Zhou, H. He et al., "A novel rhodamine B-based "off-on" fluorescent sensor for selective recognition of copper (II) ions," Talanta, vol. 184, pp. 143-148, 2018.

[39] L. Xu, S. Wei, Q. Diao et al., "Sensitive and selective rhodamine-derived probes for fluorometric sensing of $\mathrm{pH}$ and colorimetric sensing of $\mathrm{Cu}^{2+}, "$ Sensors and Actuators B: Chemical, vol. 246, pp. 395-401, 2017.

[40] X. Wang, J. Tao, X. Chen, and H. Yang, "An ultrasensitive and selective "off-on" rhodamine-based colorimetric and fluorescent chemodosimeter for the detection of $\mathrm{Cu}^{2+}$," Sensors and Actuators B: Chemical, vol. 244, pp. 709-716, 2017.

[41] D. Wu, W. Huang, C. Duan, Z. Lin, and Q. Meng, "Highly sensitive fluorescent probe for selective detection of $\mathrm{Hg}^{2+}$ in DMF aqueous media," Inorganic Chemistry, vol. 46, no. 5, pp. 1538-1540, 2007.

[42] Y. Xiang, A. Tong, P. Jin, and Y. Ju, "New fluorescent rhodamine hydrazone chemosensor for $\mathrm{Cu}(\mathrm{II})$ with high selectivity and sensitivity," Organic Letters, vol. 8, no. 13, pp. 2863-2866, 2006.

[43] M. Fischer and J. Georges, "Fluorescence quantum yield of rhodamine $6 \mathrm{G}$ in ethanol as a function of concentration using thermal lens spectrometry," Chemical Physics Letters, vol. 260, no. 1-2, pp. 115-118, 1996.

[44] V. Dujols, F. Ford, and A. W. Czarnik, "A long-wavelength fluorescent chemodosimeter selective for $\mathrm{Cu}(\mathrm{II})$ ion in water," Journal of the American Chemical Society, vol. 119, no. 31, pp. 7386-7387, 1997. 

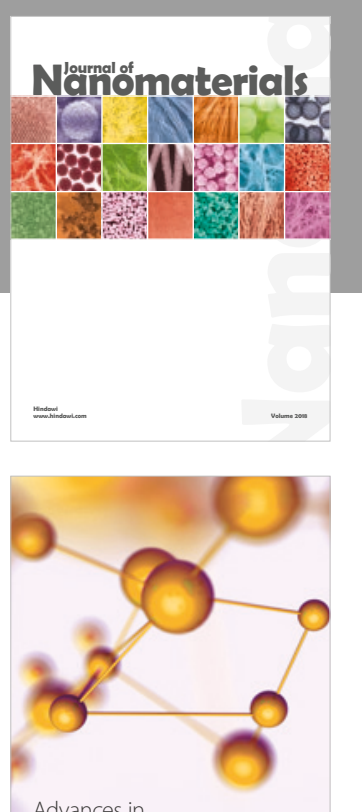

Physical Chemistry
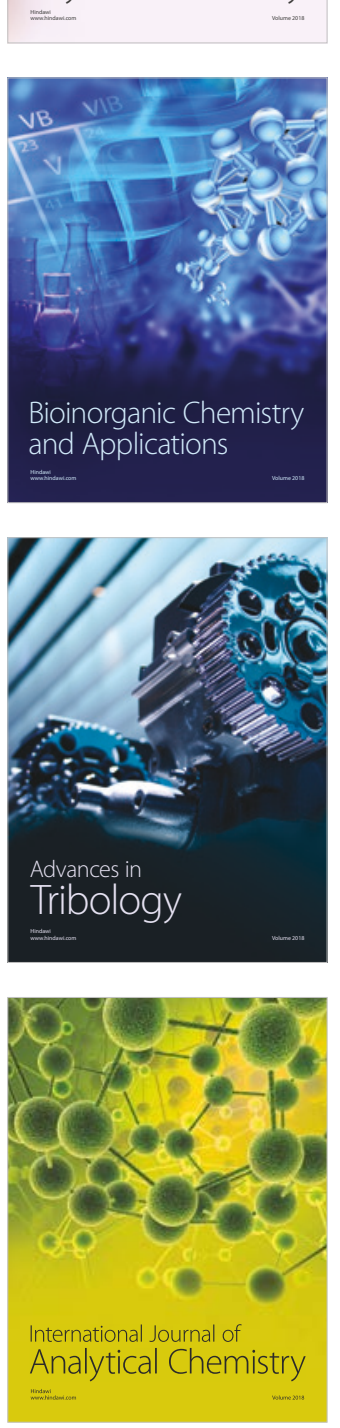

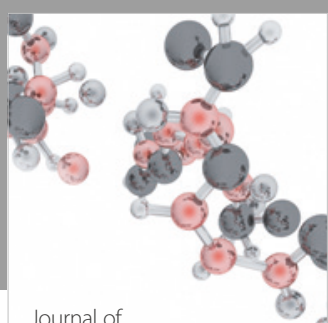

Analytical Methods

in Chemistry

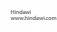

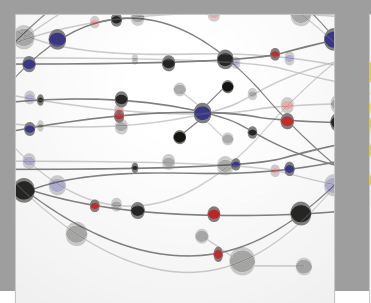

The Scientific World Journal

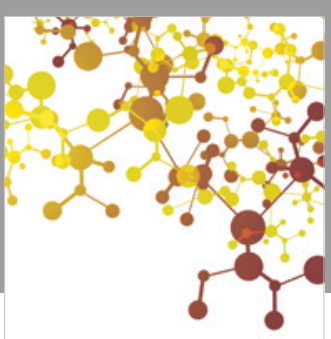

Journal of

Applied Chemistry
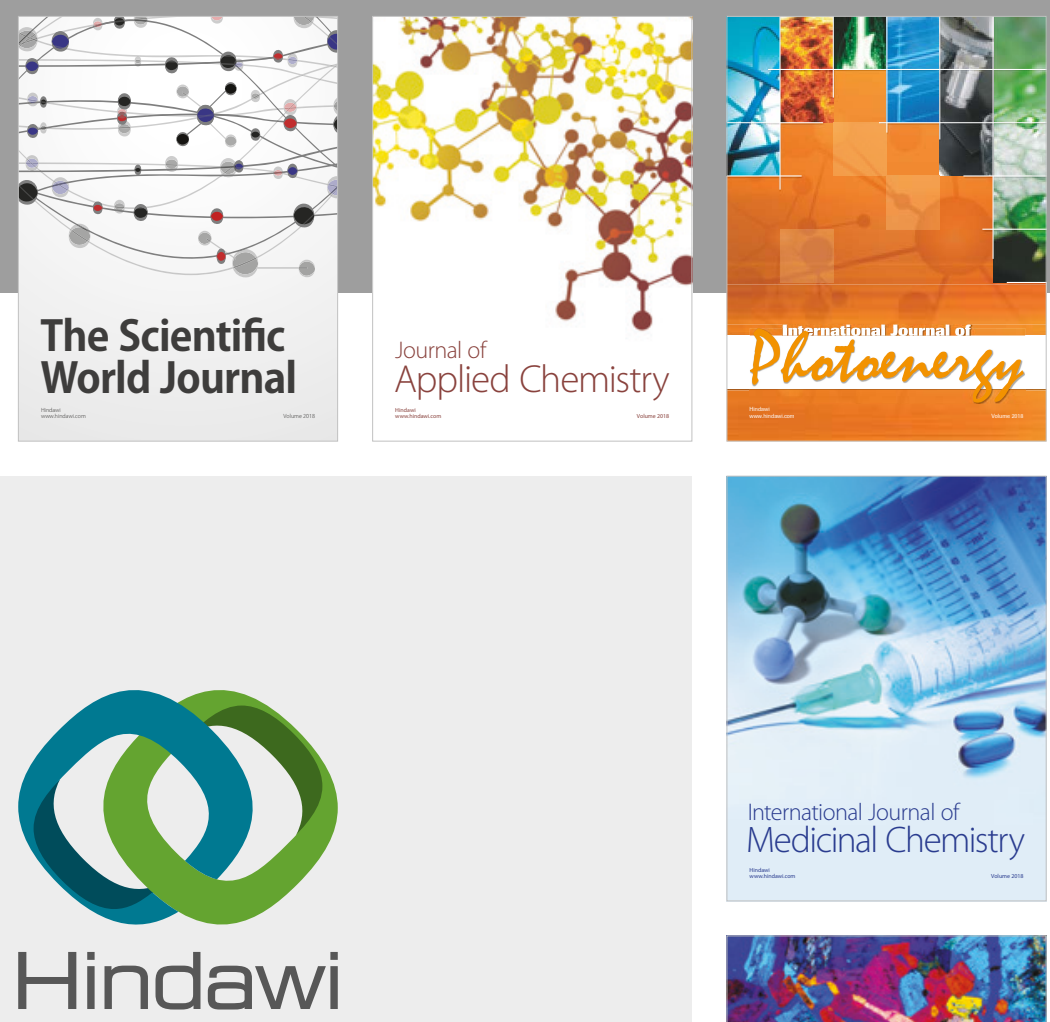

Submit your manuscripts at

www.hindawi.com
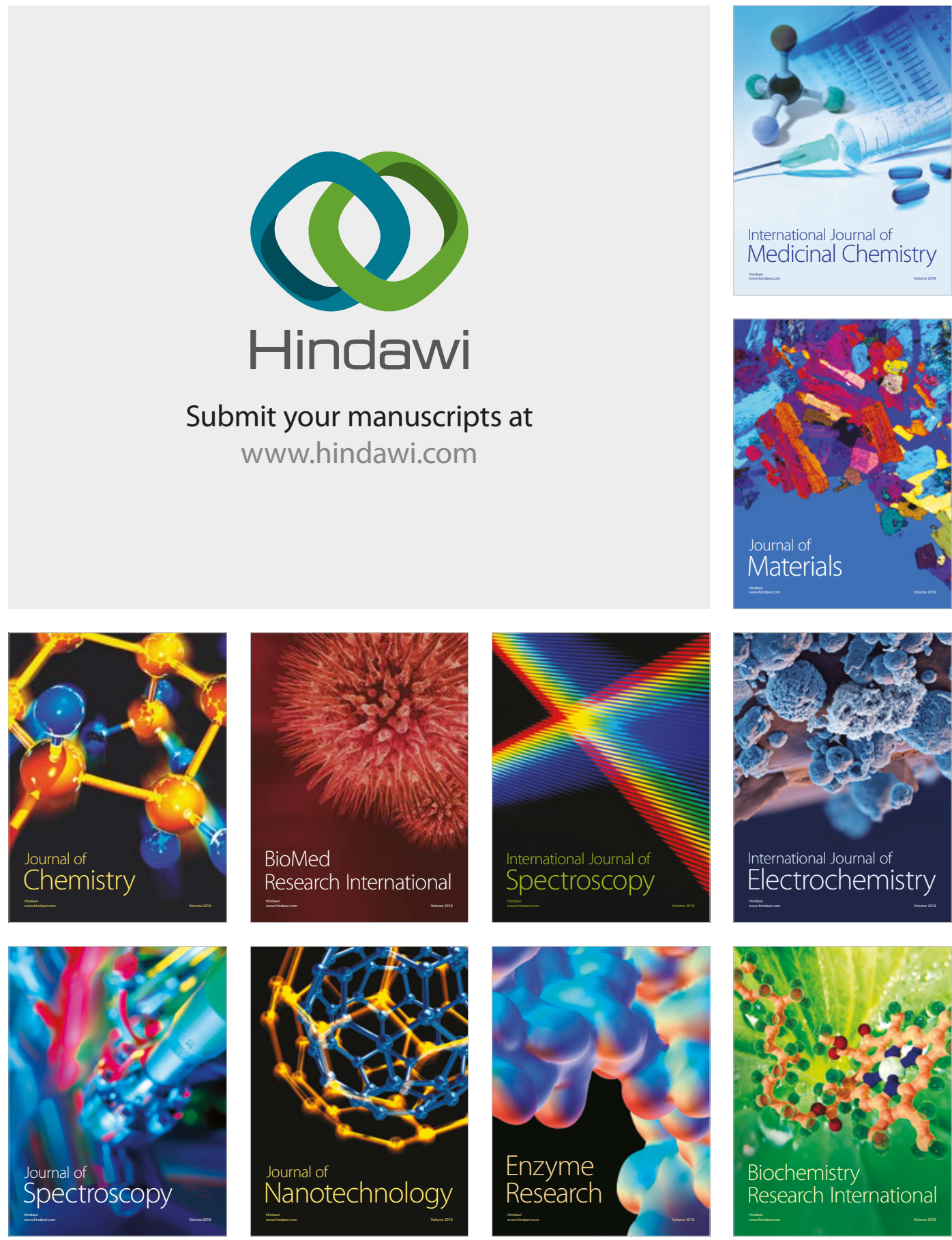
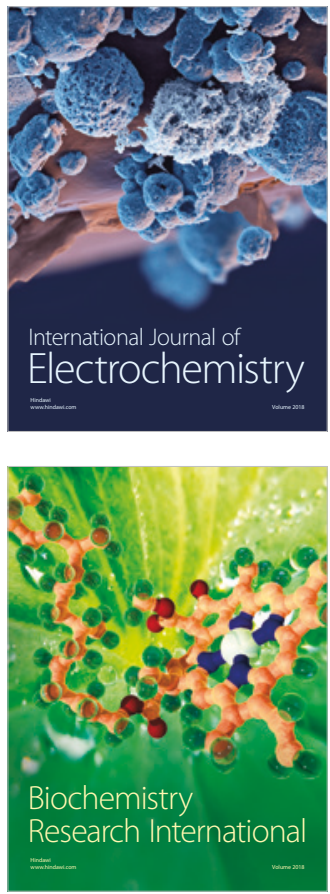